\title{
Metastatic Hepatocellular Carcinoma to the Distal Phalanx: a Case Report and Review of Literature
}

\author{
Joo-Hyun Park, M.D., Jungkwon Lee, M.D., Ph.D.*, Da-Eun Jung, M.D. ${ }^{\dagger}$, \\ Soomin Ahn, M.D. ${ }^{\dagger}$, Kyung-Min Lee, M.D. ${ }^{\dagger}$ and Bo-Kyoung Kim, M.D. ${ }^{\dagger}$ \\ Healthcare Center, Konkuk University Medical Center, Konkuk University School of Medicine, \\ Departments of *Family Medicine, Palliative Care Center, ${ }^{\dagger}$ Family Medicine, \\ ${ }^{\ddagger}$ Pathology, Samsung Medical Center, Sungkyunkwan University School of Medicine, Seoul, Korea
}

\begin{abstract}
Metastatic tumors to the hand are rare and often overlooked by clinicians. Here, we report a rare case of phalangeal metastasis of right 4th finger in a patient with hepatocellular carcinoma. Treatment was given with right 4th finger disarticulation. This report suggests that physicians must take consideration into the possibility of metastatic tumors in patients with bone lesions on hands and a history of malignancy. (Korean J Hosp Palliat Care 2012;15:108-111)
\end{abstract}

Key Words: Hepatocellular carcinoma, Neoplasm metastasis, Hand, Pain

\section{INTRODUCTION}

Metastatic tumors to the hand are rare and their incidence rate is known to be approximately $0.007 \sim 0.2 \%$ of all metastasis according to studies (1-6). Especially, bone metastasis of hepatocellular carcinoma to the hand is extremely rare. To our knowledge, only five cases have been reported in the literature (7-11). We report the case of 60 -year-old patient with metastatic hepatocellular carcinoma of the distal phalanx of the right $4^{\text {th }}$ finger and review the previously published cases with metastatic hepatocellular carcinoma to the hand.

\section{CASE REPORT}

In April 2011, a 60-year old man was admitted to our hospital and referred to palliative care center with swelling and pain of right $4^{\text {th }}$ finger tip that had started a few weeks before. His medical history included longstanding chronic viral hepatitis type B, liver cirrhosis, and hepatocellular carcinoma

Received on March 15, 2012. Revised on April 30, 2012.

Accepted on May 4, 2012.

Corresponding author: Jungkwon Lee

Tel: 02-3410-2441, Fax: 02-3410-0388

E-mail: jklee@skku.edu diagnosed seven years ago. He had undergone radiofrequency ablation (RFA) for hepatocellular carcinoma in the right lobe of the liver in May 2004. In September 2007, he had to undergo en block resection of right chest wall including $8^{\text {th }}, 9^{\text {th }}$ ribs and partial right hemidiaphragm for recurrent hepatocellular carcinoma in the intercostal muscle which were thought to be RFA track seeding. In December 2008 and May 2010, he had received palliative radiotherapy for recurrent hepatocellular carcinoma of right lobe and portal vein thrombosis but the disease had progressed and metastasized to the lung. From October 2010 to February 2011, he had received two cycles of sorafenib and two cycles of everolimus but the responses of both chemotherapies had been progressive disease of recurrent hepatocellular carcinoma.

On physical examination when admitted, he was afebrile at $36^{\circ} \mathrm{C}$ and the vital signs were stable. He had presented a globular swelling, erythema, tenderness and external wound on the right $4^{\text {th }}$ finger tip.

His performance status was Eastern Cooperative Oncology Group (ECOG) scale 2.

Laboratory investigations showed leukocytosis, prothrombin time prolongation and elevation of aspartate aminotransferase, alkaline phosphatase, gamma-glutamyl transferase, alpha fetoprotein (AFP), protein induced by vitamin $\mathrm{K}$ absence or antagonist II (PIVKA-II) level (Table 1). Serum calcium level 
was within normal limits. Culture study of right $4^{\text {th }}$ finger tip wound showed the growth of Enterobacter cloacae species. $\mathrm{X}$-ray of right hand showed extensive osteolytic bone lesion with soft tissue swelling of right $4^{\text {th }}$ distal phalanx (Figure 1).

We started pain control and antibiotic treatment on the impression of osteomyelitis and soft tissue infection of right $4^{\text {th }}$ finger. Despite the antibiotic treatment for 1 week, the swelling and pain of right $4^{\text {th }}$ finger had been aggravated and become poorly controlled. On the orthopedic surgical consultation, the patient finally had undergone right $4^{\text {th }}$ finger disarticulation at proximal interphalangeal joint level and the symptoms were improved. The specimen showed a hemorrhagic and necrotic soft tissue mass, measuring $2.5 \times 2 \mathrm{~cm}$ and

Table 1. Laboratory Findings on Admission.

\begin{tabular}{|c|c|}
\hline & Value (reference range) \\
\hline White blood cell count $\left(10^{3} / \mu \mathrm{L}\right)$ & $14.28(4.0 \sim 10.0)$ \\
\hline Prothrombin Time (INR) & $1.14(0.8 \sim 1.2)$ \\
\hline $\operatorname{AST}^{*}(\mathrm{U} / \mathrm{L})$ & $72(7 \sim 38)$ \\
\hline $\operatorname{ALT}^{\dagger}(\mathrm{U} / \mathrm{L})$ & $27(4 \sim 43)$ \\
\hline Alkaline phosphatase $(\mathrm{U} / \mathrm{L})$ & $802(40 \sim 129)$ \\
\hline Gamma glutamyl transferase $(\mathrm{U} / \mathrm{L})$ & $394(12 \sim 73)$ \\
\hline Total bilirubin $(\mathrm{mg} / \mathrm{dL})$ & $1.2(0.2 \sim 1.2)$ \\
\hline Alpha fetoprotein $(\mathrm{ng} / \mathrm{mL})$ & $108.2(0 \sim 11.9)$ \\
\hline PIVKA-II $^{\ddagger}(\mathrm{mAU} / \mathrm{mL})$ & $494(0 \sim 40)$ \\
\hline Uric acid $(\mathrm{mg} / \mathrm{dL})$ & $2.1(2.5 \sim 7.5)$ \\
\hline
\end{tabular}

*AST: aspartate aminotransferase, ${ }^{\dagger}$ ALT: alanine aminotransferase, ${ }^{\ddagger}$ PIVKA-II: protein induced by vitamin $\mathrm{K}$ absence or antagonist II.

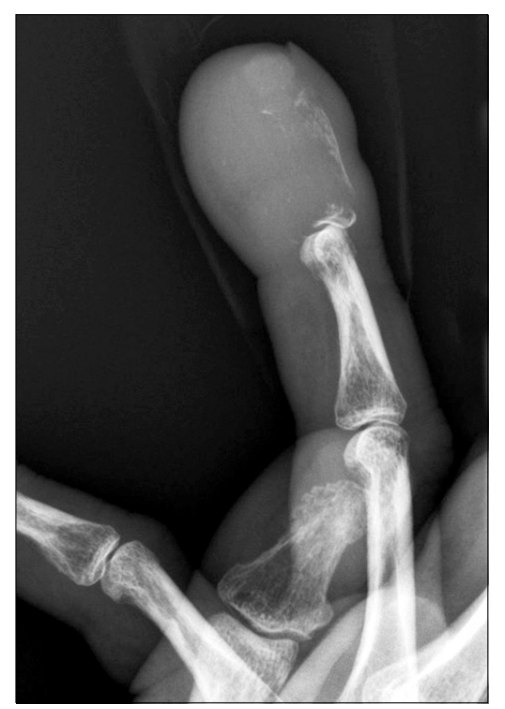

Figure 1. X-ray of the right $4^{\text {th }}$ distal phalanx showing extensive osteolytic bone lesion with soft-tissue swelling. located at the tip of finger. The pathology revealed the metastatic hepatocellular carcinoma of the distal phalangeal bone (Figure 2) and immunostaining using hepatocyte-specific antigen (clone OCH1E5, dilution 1:200, DAKO Denmark) showed positivity, which supported the pathology result. A few weeks later, right $3^{\text {rd }}$ finger swelling and pain had also developed (Figure $3 \mathrm{~A}$ ) and $\mathrm{X}$-ray of right $3^{\text {rd }}$ finger showed also osteolytic bone lesion (Figure 3B). It was thought to be

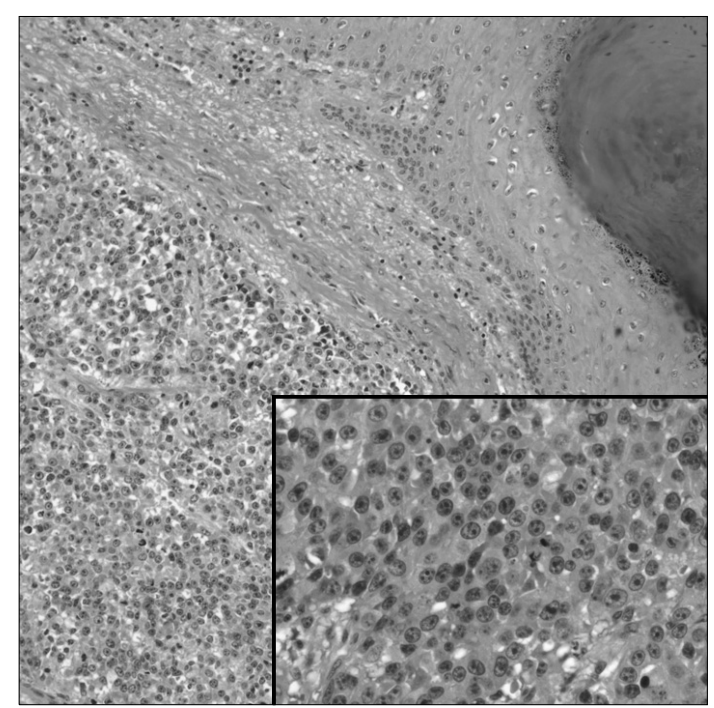

Figure 2. Metastasis of hepatocellular carcinoma, showing sheet-like arrangement of carcinoma cells separated by sinusoid-like thin-walled vessels $(H \& E$ stain, $\times 200)$. Inset shows cellular detail of the carcinoma (H\&E stain, $\times 400)$.
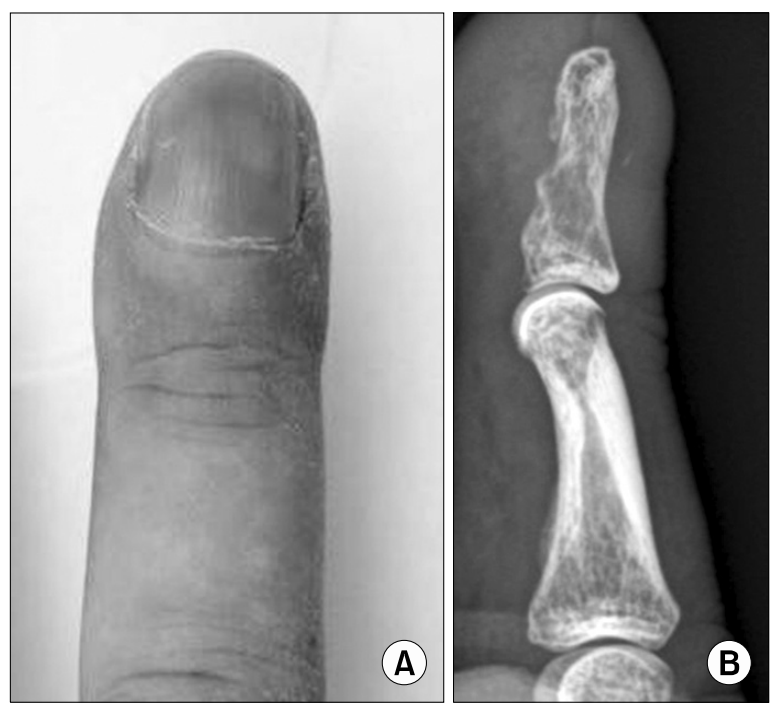

Figure 3. Appearance (A) and X-ray (B) of the right $3^{\text {rd }}$ distal phalanx. 
Table 2. Literature Review of Previously Published 5 Cases and a Current Case of Metastatic Hepatocellular Carcinoma to the Hand.

\begin{tabular}{llll}
\hline & \multicolumn{1}{c}{ Location of hand metastasis } & \multicolumn{1}{c}{ Treatment } & \multicolumn{1}{c}{ Prognosis } \\
\hline Reichbach et al. $^{\dagger}$ & Distal phalanx of thumb & Amputation of finger & Died 7 months later \\
Delsmann et al. & First metacarpal bone & Surgical resection +tamoxifen & Died 15 months later \\
Lee et al. $^{\ddagger}$ & Distal phalanx of thumb & Disarticulation of the carpometacarpal joint & Died 5 months later \\
Fontana et al. & Second phalanx of $2^{\text {nd }}$ and $3^{\text {rd }}$ finger & Surgical ablation & Died 4 months later \\
Otsuji et al. & Distal phalanx of $4^{\text {th }}$ finger & Disarticulation of finger & Alive for 14 months \\
Current case & Distal phalanx of $3^{\text {rd }}$ and $4^{\text {th }}$ finger & Disarticulation of finger & Died 2 months later \\
\hline
\end{tabular}

*Source: Reichbach EJ, Levinson JD, Fagin RR. Unusual osseous metastases of hepatoma. JAMA 1970;213:2078-9, ' Source: Delsmann BM, Lienemann A, Nerlich A, Hoffmann E, Caselmann WH, Refior HJ. Primary manifestation of hepatocellular carcinoma as osteolytic hand metastasis--a case report. Z Orthop Ihre Grenzgeb 1998;136:571-3, ${ }^{\ddagger}$ Source: Lee KS, Lee SH, Kang KH, Oh KJ. Metastatic hepatocellular carcinoma of the distal phalanx of the thumb. Hand Surg 1999;4:95-100, ${ }^{\S}$ Source: Fontana T, Siciliano M, Franceschelli A, Annicchiarico BE, Rossi P, Bigotti G, et al. An atypical bone metastasis of hepatocellular carcinoma: case report and review of the literature. Clin Ter 2004;155:447-51, "Source: Otsuji M, Matsunaga S, Koga H, Kawabata N, Imakiire T, Hiwaki T, et al. An atypical extrahepatic metastasis of the distal phalanx from hepatocellular carcinoma. Int J Clin Oncol 2009;14:159-62.

another phalangeal metastasis. However, he received only supportive management due to rapid decline of his performance. He died 2 months after first diagnosis of finger metastasis.

\section{DISCUSSION}

Incidence rate of metastatic tumor of the hand is extremely low (1-6). Chief origins of the metastatic tumors of the hands are lung cancer, followed by kidney and breast cancer (12-14). In case of hepatocellular carcinoma, the incidence of bone metastasis after liver resection ranges from $2.1 \%$ to $3.7 \%$ according to the studies (15-17). However, major sites of bone metastasis from hepatocellular carcinoma are spine, pelvic bone, and ribs (17-19). Until now, only a few cases with hand metastasis from hepatocellular carcinoma have been reported in the literature as shown in Table 2.

Metastatic site was phalangeal bone in five cases (including current case) and metacarpal bone in one case. All patients received palliative surgical treatment of amputation or disarticulation of the finger or hand bone.

Hand metastasis from any primary malignancy usually presented at the late stage of metastatic dissemination and survival of these patients with metastatic hand tumors was generally poor.

Metastatic tumor of the hand has its clinical significance for the following reason despite its rarity and poor prognosis. At presentation, the symptoms such as pain and swelling are non-specific. Because of the acute inflammatory symptoms and signs, clinician may overlook or mistake the symptoms as those of other benign causes of bone pain, such as osteomyelitis, soft tissue infection, osteoarthritis, and gout. In the current case, we initially treated the patient on the impression of osteomyelitis and soft tissue infection for 1 week and delayed some time for the definite diagnosis and the effective pain control.

Plain radiographs are helpful in diagnosis but they show the lesion only after the considerable size of bone has been replaced by malignant tissue. Thus bone scan is more effective in the early detection of occult lesions (20). Considering the progressive nature of metastatic tumors, the prompt palliative treatment is needed. Surgical treatment such as amputation, disarticulation and wide resection may be preferred due to the simplicity of approach, economy of time, minimal side effect, cost-effectiveness.

In conclusion, we suggest that this is one of the rare cases presenting a phalangeal bone metastasis from hepatocellular carcinoma and clinicians should consider metastatic tumor of the hands as a differential diagnosis in patients with osteolytic bone lesion on hands and a history of malignancy of other organs. Early diagnosis and proper management can improve the patients' quality of life and make them more comfortable.

\section{요 약}

손으로의 전이성 암은 드문 질환으로 환자를 진료함 에 있어 간과되기 쉽다. 간세포성 암종 환자에서 손으 로의 전이는 지금까지 전세계적으로 5예가 보고되고 있 으며, 이 논문에서는 간세포성 암종의 우측 4 번째 손가 
락으로의 전이를 보고하고자 한다. 환자는 통증과 부종 을 호소하였으며 보존적 치료에도 증상이 점차 악화되 어 절단 수술을 받고 증상이 호전되었다. 이 보고는 진 료의사들이 암환자의 손에 병변이 관찰될 때 전이성 암 의 가능성을 염두에 두고 접근하여 증상 조절을 해야 한다는 것을 시사한다.

중심단어: 간세포 암종, 암 전이, 손, 통증

\section{REFERENCES}

1. Ozcanli H, Ozdemir H, Ozenci AM, Söyüncü Y, Aydin AT. Metastatic tumors of the hand in three cases. Acta Orthop Traumatol Turc 2005;39:445-8.

2. Basora J, Fery A. Metastatic malignancy of the hand. Clin Orthop Relat Res 1975;208:182-6.

3. Kerin R. Metastatic tumors of the hand. A review of the literature. J Bone Joint Surg Am 1983;65:1331-5.

4. Sim FH, Pritchard DJ. Metastatic disease in the upper extremity. Clin Orthop Relat Res 1982;169:83-94.

5. Wu KK, Guise ER. Metastatic tumors of the hand: a report of six cases. J Hand Surg Am 1978;3:271-6.

6. Kumar PP, Kovi J. Metastases to bones of the hands and feet. J Natl Med Assoc 1978;70:837-40.

7. Otsuji M, Matsunaga S, Koga H, Kawabata N, Imakiire T, Hiwaki T, et al. An atypical extrahepatic metastasis of the distal phalanx from hepatocellular carcinoma. Int J Clin Oncol 2009;14: 159-62.

8. Reichbach EJ, Levinson JD, Fagin RR. Unusual osseous metastases of hepatoma. JAMA 1970;213:2078-9.

9. Delsmann BM, Lienemann A, Nerlich A, Hoffmann E, Caselmann WH, Refior HJ. Primary manifestation of hepatocellular carcinoma as osteolytic hand metastasis--a case report. Z Orthop Ihre
Grenzgeb 1998;136:571-3.

10. Lee KS, Lee SH, Kang KH, Oh KJ. Metastatic hepatocellular carcinoma of the distal phalanx of the thumb. Hand Surg 1999;4:95-100.

11. Fontana T, Siciliano M, Franceschelli A, Annicchiarico BE, Rossi P, Bigotti G, et al. An atypical bone metastasis of hepatocellular carcinoma: case report and review of the literature. Clin Ter 2004;155:447-51.

12. Kerin R. The hand in metastatic disease. J Hand Surg Am 1987; 12:77-83.

13. Healey JH, Turnbull AD, Miedema B, Lane JM. Acrometastases. A study of twenty-nine patients with osseous involvement of the hands and feet. J Bone Joint Surg Am 1986;68:743-6.

14. Flynn CJ, Danjoux C, Wong J, Christakis M, Rubenstein J, Yee A, et al. Two cases of acrometastasis to the hands and review of the literature. Curr Oncol 2008;15:51-8.

15. Kanda M, Tateishi R, Yoshida H, Sato T, Masuzaki R, Ohki T, et al. Extrahepatic metastasis of hepatocellular carcinoma: incidence and risk factors. Liver Int 2008;28:1256-63.

16. Taketomi A, Toshima T, Kitagawa D, Motomura T, Takeishi K, Mano Y, et al. Predictors of extrahepatic recurrence after curative hepatectomy for hepatocellular carcinoma. Ann Surg Oncol 2010; 17:2740-6.

17. Taki Y, Yamaoka Y, Takayasu T, Ino K, Shimahara Y, Mori K, et al. Bone metastases of hepatocellular carcinoma after liver resection. J Surg Oncol 1992;50:12-8.

18. Liaw CC, Ng KT, Chen TJ, Liaw YF. Hepatocellular carcinoma presenting as bone metastasis. Cancer 1989;64:1753-7.

19. Kim S, Chun M, Wang H, Cho S, Oh YT, Kang SH, et al. Bone metastasis from primary hepatocellular carcinoma: characteristics of soft tissue formation. Cancer Res Treat 2007;39:104-8.

20. Bryan RS, Soule EH, Dobyns JH, Pritchard DJ, Linscheid RL. Metastatic lesions of the hand and forearm. Clin Orthop Relat Res 1974;101:167-70. 